Leafminer flies (Diptera: Agromyzidae) are a highly diverse group of exclusively phytophagous species and they comprise more than 3000 known species worldwide (Braun et al. 2008; Shahreki et al. 2012). Damage is caused by larval feeding in the spongy mesophyll layer of the leaf and by the feeding and oviposition punctures of the females. The feeding punctures, referred to as stippling, can decrease photosynthesis and create entry sites for plant pathogens. Larval mining can also decrease photosynthesis rate and can reduce tissue conductance (Rauf et al. 2000; Chow \& Heinz 2004). Sasakawa (1997) recorded 11 species of agromyzid flies from Ryukyus, Japan. Shiao \& Wu (1999) worked on the subfamily Agromyzinae of Taiwan and recorded 38 species under 15 genera. Sehgal et al. (1980) have reported 11 species of agromyzid flies associated with 25 different species of leguminous host plants in northern India. In addition, Thapa (2011) has reported 28 species of agromyzid flies belonging to seven genera reared and described on 34 different leguminous host-plants from Pantnagar, Nainital, northern India. Benavent-Corai et al. (2005) published a research article from Brazil on host-plant interactions where eight agromyzid species were reared from 18 plant species of the family Asteraceae. In Poland, about a dozen species of agromyzid leafminers occur on cereals and locally they might occur in high abundance (Walczak \& Roik 2010). Scheffer \& Lewis (2005), Scheffer et al. (2006, 2007) and Winkler et al. (2009) worked on the molecular phylogeny and systematics of agromyzid flies.

In Bangladesh, agomyzids were reported by

\section{VEGETABLE LEAFMINERS (DIPTERA: AGROMYZIDAE) AND THEIR PLANT HOSTS IN BANGLADESH}

\author{
Santosh Mazumdar ${ }^{1}$ \& Badrul Amin Bhuiya ${ }^{2}$ \\ 1,2 Department of Zoology, University of Chittagong, \\ Chittagong 4331, Bangladesh \\ ${ }^{1}$ mazumdarsantosh@gmail.com (corresponding author), \\ ${ }^{2}$ badrulbhuiya@yahoo.com
}

different authors (Rahman et al. 1983; Ahmed 2005; Bhuiya et al. 2011). Information on the host plants of Liriomyza sp. is also available for Bangladesh (Akter et al. 2001; Bhuiya et al. 2010). In the present paper, four agromyzid leafminers Liriomyza chinensis (Kato), L. sativae Blanchard Melanagromyza obtusa Malloch and Ophiomyia phaseoli (Tryon) and their 17 plant hosts from Bangladesh are being reported.

Meterials and Methods: Field study was carried out from January 2011-April 2013 in different cultivated vegetable fields of Bangladesh. Leafminer infested leaves were brought to the laboratory and kept in a controlled environment: temperature $\left(23 \pm 1{ }^{\circ} \mathrm{C}\right)$ and humidity $(67 \pm 2 \% \mathrm{RH})$. Leaves of different host plants were placed in plastic rearing boxes $(15 \times 25$ $\mathrm{cm}$ ) with rectangular holes covered with a fine screen for ventilation. Emerging vegetable leafminers were collected and preserved for identification. Lastly, 17 vegetables were confirmed as plant hosts of reared agromyzid flies. The pin and card mounted specimens were imaged with a digital 3D imaging microscope. For identification of leafminer flies keys provided by Sasakawa (1961, 1963a,b), Spencer (19730), Spencer \& Steyskal (1986), Shiao et al. (1991), Shiao \& Wu (1999),

DOI: http://dx.doi.org/10.11609/JoTT.o3892.5894-9 | ZooBank: urn:Isid:zoobank.org:pub:C95EA3DB-E690-42B4-BF97-C8F32776C5BE

Editor: R.M. Sharma (Retd.), Zoological Survey of India, Pune, India.

Date of publication: 26 June 2014 (online \& print)

Manuscript details: Ms \# 03892 | Received 30 December 2013 | Final received 21 April 2014 | Finally accepted 29 May 2014

Citation: Mazumdar, S. \& B.A. Bhuiya (2014). Vegetable leafminers (Diptera: Agromyzidae) and their plant hosts in Bangladesh. Journal of Threatened Taxa 6(6): 5894-5899; http://dx.doi.org/10.11609/JoTT.03892.5894-9

Copyright: (C) Mazumdar \& Bhuiya 2014. Creative Commons Attribution 4.0 International License. JoTT allows unrestricted use of this article in any medium, reproduction and distribution by providing adequate credit to the authors and the source of publication.

Funding: This study has been partially funded by USDA.

Competing Interest: The authors declare no competing interests.

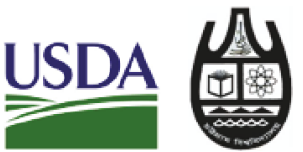

Acknowledgements: The authors sincerely thank Dr. Mostafa Kamal Pasha, Professor, Department of Botany, University of Chittagong, Bangladesh, for identification of agromyzid plant hosts; Dr. Sonja Scheffer and Dr. Michael Gates of Systematic Entomology Laboratory, USDA for confirming identification the leafminer L. sativae. 
Zhu et al. (2002), Dempewolf (2004), and Shiao (2004) were followed. Some critical specimens were sent to the taxonomist of Systematic Entomology Laboratory, $\mathrm{NMNH}$, Smithsonian Institution, Washington, D.C. for confirmation. All identified specimens have been deposited in the Insect Museum, Department of Zoology, University of Chittagong, Bangladesh.

Results: Four vegetable leafminers were reared from the 17 collected vegetables (Table 1 ).

Table 1. List of reared vegetable leafminers and their host plants.

\begin{tabular}{|c|c|c|c|}
\hline & $\begin{array}{l}\text { Scientific name of } \\
\text { vegetable leafminer }\end{array}$ & $\begin{array}{l}\text { Subfamily } \\
\text { of vegetable } \\
\text { leafminer }\end{array}$ & $\begin{array}{l}\text { Scientific name of host } \\
\text { plants with common name in } \\
\text { parenthesis }\end{array}$ \\
\hline 1 & $\begin{array}{l}\text { Liriomyza chinensis } \\
\text { (Kato, 1949) }\end{array}$ & \multirow{15}{*}{ Phytomyzinae } & Allium cepa L. (Onion) \\
\hline \multirow{14}{*}{2} & \multirow{14}{*}{$\begin{array}{l}\text { Liriomyza sativae } \\
\text { Blanchard, } 1938\end{array}$} & & $\begin{array}{l}\text { Brassica juncea (L.) Czern } \\
\text { (Indian mustard) }\end{array}$ \\
\hline & & & $\begin{array}{l}\text { Brassica olereacea var } \\
\text { botrytis L. (Cauliflower) }\end{array}$ \\
\hline & & & $\begin{array}{l}\text { Brassica oleracea var.capitata } \\
\text { L. (Cabbage) }\end{array}$ \\
\hline & & & $\begin{array}{l}\text { Brassica rapa L. subsp. rapa } \\
\text { (Turnip) }\end{array}$ \\
\hline & & & $\begin{array}{l}\text { Citrullus lanatus (Thunb.) } \\
\text { Matsum. \& Nakai (Water } \\
\text { Melon) }\end{array}$ \\
\hline & & & $\begin{array}{l}\text { Cucumis melo L. var. melo } \\
\text { (Musk Melon) }\end{array}$ \\
\hline & & & Cucumis sativa L. (Cucumber) \\
\hline & & & $\begin{array}{l}\text { Cucurbita maxima Duchesne } \\
\text { (Sweet Gourd) }\end{array}$ \\
\hline & & & $\begin{array}{l}\text { Lablab purpureus (L.) Sweet } \\
\text { subsp. purpureus (Country } \\
\text { Bean) }\end{array}$ \\
\hline & & & $\begin{array}{l}\text { Phaseolus vulgaris L. (French } \\
\text { Bean) }\end{array}$ \\
\hline & & & Pisum sativum L. (Pea) \\
\hline & & & $\begin{array}{l}\text { Solanum lycopersicum L } \\
\text { (Tomato) }\end{array}$ \\
\hline & & & $\begin{array}{l}\text { Solanum melongena } \mathrm{L} . \\
\text { (Brinjal) }\end{array}$ \\
\hline & & & $\begin{array}{l}\text { Vigna unguiculata (L.) Walp. } \\
\text { (Cowpea) }\end{array}$ \\
\hline \multirow{3}{*}{3} & \multirow{3}{*}{$\begin{array}{l}\text { Melanagromyza } \\
\text { obtusa Malloch, } 1914\end{array}$} & \multirow{6}{*}{ Agromyzinae } & $\begin{array}{l}\text { Glycine max (L.) Merr. (Soya } \\
\text { Bean) }\end{array}$ \\
\hline & & & $\begin{array}{l}\text { Lablab purpureus (L.) Sweet } \\
\text { subsp. purpureus (Country } \\
\text { Bean) }\end{array}$ \\
\hline & & & $\begin{array}{l}\text { Phaseolus aureus Roxb. } \\
\text { (Mung Bean) }\end{array}$ \\
\hline \multirow{3}{*}{4} & \multirow{3}{*}{$\begin{array}{l}\text { Ophiomyia phaseoli } \\
\text { (Tryon, 1895) }\end{array}$} & & $\begin{array}{l}\text { Lablab purpureus (L.) Sweet } \\
\text { subsp. purpureus (Country } \\
\text { Bean) }\end{array}$ \\
\hline & & & $\begin{array}{l}\text { Solanum lycopersicum L } \\
\text { (Tomato) }\end{array}$ \\
\hline & & & $\begin{array}{l}\text { Vigna unguiculata (L.) Walp. } \\
\text { (Cowpea) }\end{array}$ \\
\hline
\end{tabular}

\section{Liriomyza chinensis (Kato, 1949) (Image 1)}

Liriomyza chinensis (Kato, 1949) comb. and stat. nov. Spencer, 1973, Agromyzidae (Diptera) of economic importance: 164.

Diagnostic characters: Body length $1.3 \mathrm{~mm}$; head largely yellow, face, genae and postgenae yellow; occiput and vertical angles brown; orbits slightly brownish-tinged; lunule low semicircular; third antennal segment distinctly angulate, with distinct point at upper corner; wing length $1.3-2.0 \mathrm{~mm}$; mesonotum greyishblack, scutellum entirely dark, femora yellow. In female ninth sternite bearing eight marginal setae.

Host plants: A. cepa (Onion) (present study); A. cepa, A. bakeri, $A$. fistulosum, and A. odorum (Sasakawa 1961); A. porrum (Martinez, 1982).

Distribution: Bangladesh: Rajshahi (present work), Taiwan, Thailand, Vietnam, France, China, Indonesia, Japan, Republic of Korea, Malaysia and Singapore (Martinez 1982).

Material studied: IMZDCU 004, 1 male, 14.iii.2011, ex. A. cepa, Ramchandrapur, Rajshahi, Bangladesh, coll. S. Mazumdar.

\section{Liriomyza sativae Blanchard, 1938 (Image 2)}

Liriomyza sativae Blanchard, 1938: An. Soc. Cient. Santa Fe, 126: 352.

Diagnostic characters: Body length $1.12 \mathrm{~mm}$; mat gray with black and yellow spots; upper orbit darkened; mesopleuron yellow, black marking along the lower, front, and hind margins; femora yellow; wing length

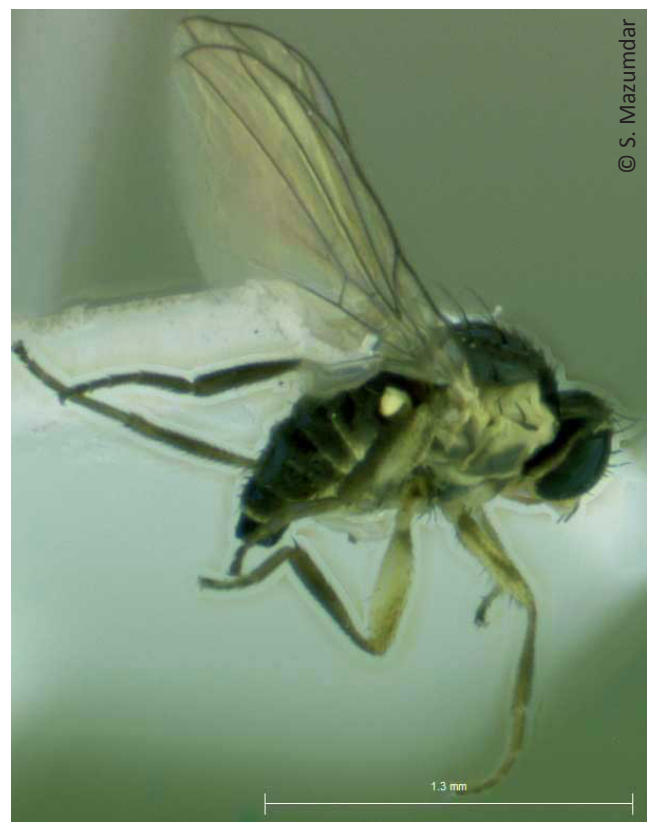

Image 1. Liriomyza chinensis (Kato, 1949) 


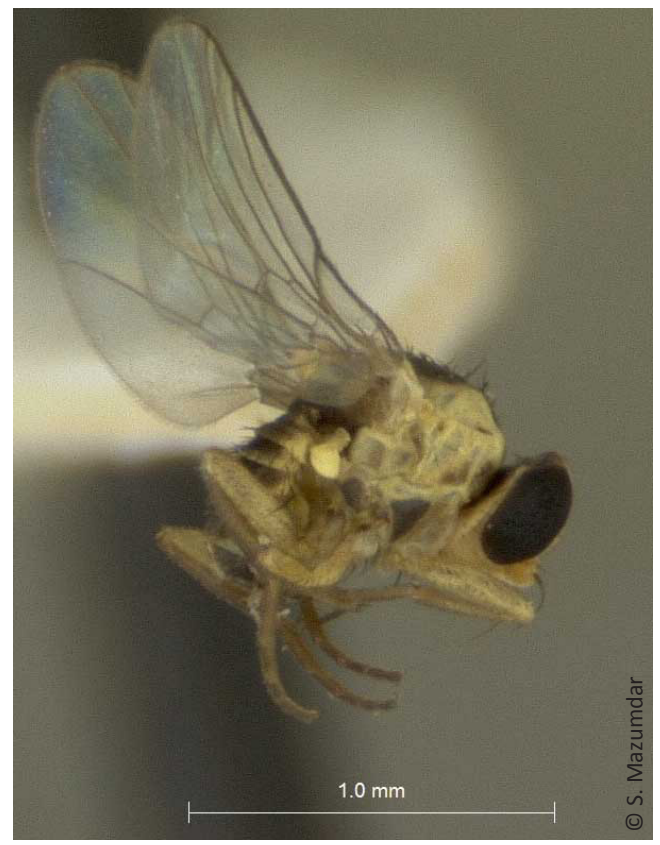

Image 2. Liriomyza sativae Blanchard, 1938

1.3-1.7 $\mathrm{mm}$; orbital setulae sparse, reclinate; third antennal segment small, round; mesonotum brilliantly shining black; three post-sutural and one presutural dorsocentral bristles, acrostichal bristles irregularly in four rows; squamae yellowish, margin and fringe dark; a vertical margin in the $2^{\text {nd }}$ abdominal segment.

Host plants: B. juncea (Indian mustard), B. olereacea (Cauliflower); B. oleracea (Cabbage), B. rapa (Turnip), C. lanatus (Water melon), S. lycopersicum L (Tomato); S. melongena (Brinjal), C. melo (Musk Melon); C. sativa (Cucumber), C. maxima (Sweet Gourd) L. purpureus (Country Bean); P. vulgaris (French Bean), P. sativum (Pea), V. unguiculata (Cowpea); (present study); $P$. vulgaris (French Bean) (Zhao \& Kang 2002).

Distribution: Bangladesh (Bhuiya et al. 2011); North, South, and Central America. In the Pacific it is present in Tahiti, Guam, New Caledonia, American and Western Samoa, Vanuatu, Cook Is. and Hawaii, Jamaica (Spencer 1965); Argentina, Peru, Venezuela (Spencer 1973); Yemen, Oman (Deeming 1992); Sudan, Cameroon (Martinez \& Bordat 1996), Nigeria (Deeming \& Mann 1999). Japan, Vietnam, Turkey, Indonesia and India (Sasakawa 1961).

Material studied: IMZDCU 005, 2 males and 9 females, 16.vii.2011, ex. S. lycopersicum, Chittagong, BARI, Hathazari, coll. S. Mazumdar.

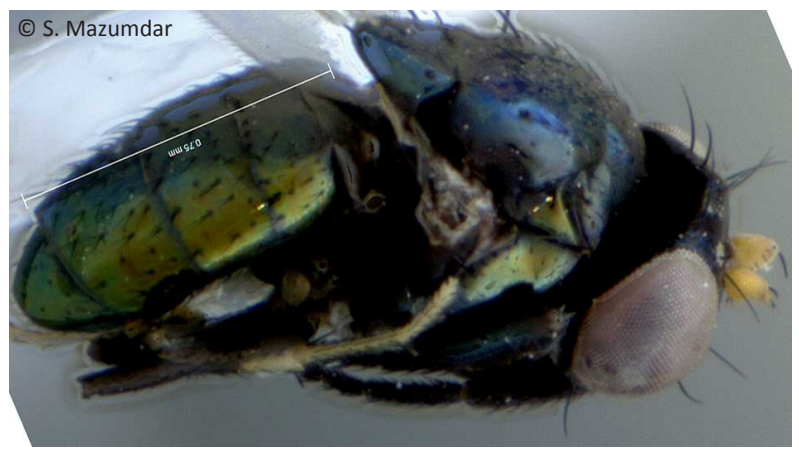

Image 3. Melanagromyza obtusa Malloch, 1914

Melanagromyza obtusa Malloch, 1914 (Image 3)

Agromyza obtusa Mali., 1914, Ann. Hist.-Nat. Mus. Hung. 12: 323.

Melanagromyza obtusa Malloch, 1914

Diagnostic characters: Body length $1.60 \mathrm{~mm}$, fringe on calypter white to yellowish; ocellar triangle large, extending to dorsal margin of lunule; mesonotum distinctly bluish shining; abdomen greenish; antennae and legs completely black; halters black with light brown stalk lets, fore tibia without bristle; wing length $1.25 \mathrm{~mm}$.

Host plants: L. purpureus (Country Bean), G. max (Soya Bean), P. aureus (Mung Bean) and V. unguiculata (Cowpea) (present work); Cajanus (Arhar), Dunbaria (Heyne's Pegionpea); Flemingia (Slender Fremingia); Rhynchosia (Himalayan Snoutbean), and Tephrosia (White Hoary Pea) (Shanower et al. 1998).

Distribution: Bangladesh: Chittagong, CU campus; Hathazari; Cox's Bazar, St. Martin's Island (present work); India (Yadav \& Yadav 2013); Myanmar, Nepal, Pakistan, Philippines, Thailand, Vietnam, China, Taiwan, Indonesia, Malaya, Sri Lanka, New guinea and Japan (Delfino \& Hardy 1967; Shanower et al. 1998, 1999; Spencer 1973) and Australia (Spencer 1999).

Material studied: IMZDCU 002, 2 males, 28.vii.2011, ex. L. purpureus, Chittagong, Panchlaish, coll. S. Mazumdar.

\section{Ophiomyia phaseoli (Tryon, 1895) (Image 4)}

Oscinis phaseoli Tryon, 1895: Trans. Nat. Hist. Soc. Qd. 1:4 Agromyza phaseoli Coquillett, 1899: Proc. Linn. Soc. N.S.W. 24: 128.

Diagnostic characters: Body length $1.50 \mathrm{~mm}$; frons mat gray, Gena and postgena lightly brown tinged; ocellar triangle; orbit slightly shining; orbital bristles four pairs; orbital setulae 3-4 pairs; halter, squama, and fringes milky white between $2^{\text {nd }}$ to $3^{\text {rd }}$ orbital bristles.

Host plants: L. purpureus (Country Bean), S. 


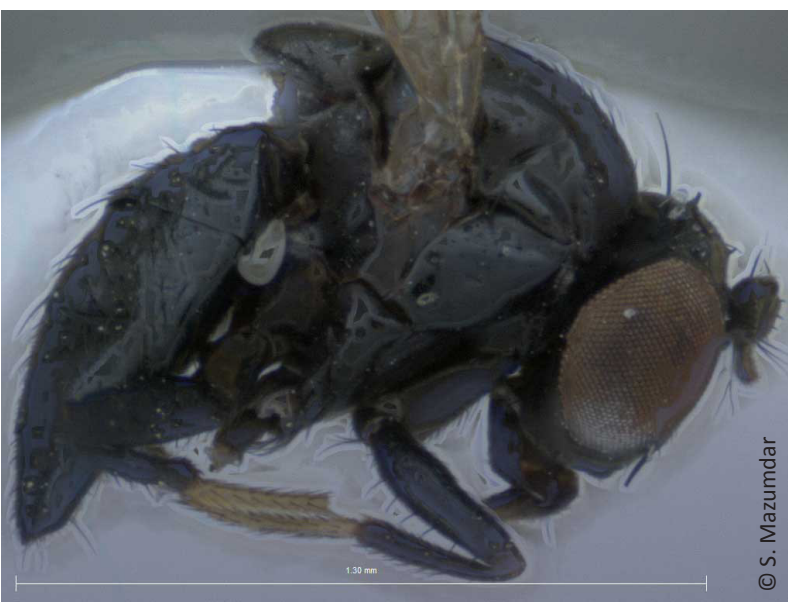

Image 4. Ophiomyia phaseoli (Tryon, 1895)

lycopersicum (Tomato) and $P$. aureus (Mung Bean) (present study), Phaseolus vulgaris, Vigna unguiculata, V. aconitifolia, V. aurea, V. calcarata, V. mungo, $V$. radiate, Cajanus cajan, Glycine max, Lablab niger (= Dolichos lablab), Pisum sativum, Canavalia ensiformis, Crotalaria juncea, C. laburnifolia, C. mucronata, Macroptilium atropurpureum, M. lathryoides, Phaseolus panduratus and $P$. semierectus (Waterhouse 1998).

Distribution: Bangladesh: Chittagong, CU campus; Hathazari; Cox's Bazar, St. Martin's Island (present work); China, Hong Kong, India, Indonesia, Iraq, Israel, Jordan, Malaysia, Myanmar, Nepal, Pakistan, Philippines, Singapore, Sri Lanka, Taiwan, Thailand, Japan, Burundi, Congo (Zaire), Egypt, Ethiopia, Kenya, Madagascar, Mauritius, Malawi, Mali, Nigeria, Reunion, Rwanda, Senegal, South Africa, Sudan, Tanzania, Uganda, Zambia, Zaire, Zimbabwe, Australia, Carolineis, Fiji, Guam, Hawaii, Micronesia, Irian, Jaya, Marianais, Papua new guinea, Samoa, Brunei and Laos (Waterhouse 1998; Shiao \& Wu 1999).

Material studied: IMZDCU 003, 2 females, 19.ii.2011, ex. L. purpureus, Chittagong, Panchlaish, coll. S. Mazumdar.

Discussion: In Bangladesh, Alam et al. (1964) and Alam (1965) listed five species of Agromyzid flies under three genera, Agromyza sp., A. ablaza, Melanagromyza cunetans, M.obtusa. and Ophiomyia phaseoli as crop pests from East Pakistan (now Bangladesh). Rahman et al. (1983) noted M. phaseoli; Biswas (2001) mentioned $O$. phaseoli and M. sozae as pests of Soybean \& Ahmed (2005) recorded Agromyza theae Cotes as tea pest. $O$. phaseoli is one of the major pests of Black Gram in Bangladesh causing serious damage to the crop (Rahman 1991; Mia 1998; Prodhan et al. 2000). In the present study the leafminers $L$. chinensis, $L$. sativae,
M. obtuse and $O$. phaseoli were reared from different plant hosts which are not recorded earlier. Moreover, $L$. chinensis was reared from Onion ( $A$. cepa) which constitutes its first record from Bangladesh together with the additional host record. It also occurs as a serious pest on Allium spp. in China, Japan, Malaysia, Singapore, Thailand (Spencer 1973, 1990; Chen et al. 2003), Korea (Hwang \& Moon 1995), Vietnam (Andersen et al. 2002) and Taiwan (Shiao 2004). L. sativae is among the most serious polyphytophagous insect pests of vegetables and ornamental plants in the world (Spencer 1973; Kang 1996). It has been spreading rapidly across Asia and is now found on the borders of the EU, i.e., in Western Turkey (Civelek et al. 2004) whereas it has been reported for the first time by Bhuiya et al. (2011) in Bangladesh. In the present study, the most common agromyzid species was Liriomyza sativae reared from Indian mustard, Cauliflower, Cabbage, Turnip, Water Melon, Tomato, Brinjal, Musk Melon, Cucumber, Sweet Gourd, Country Bean, French Bean, Pea and Cowpea. Besides, Zhao \& Kang (2002) reported French Bean as a host of $L$. sativae. Spencer (1990) noted that $M$. obtusa is not host-specific. In addition Shanower et al. (1998) reported five host plant genera in the legume family as hosts: Cajanus (e.g., Arhar), Dunbaria (e.g., Heyne's Pegionpea); Flemingia (e.g., Slender Fremingia), Rhynchosia (e.g., Himalayan Snoutbean), and Tephrosia (e.g., White Hoary Pea). This pest was reared from L. purpureus (Country Bean), G. max (Soya Bean), P. aureus (Mung Bean) and V. unguiculata (Cowpea) in the present investigation. According to Waterhouse (1998) O. phaseoli is known to attack at least 40 plant species. Most of its important hosts belong to the legume tribe Phaseoleae and particularly to the genus Phaseolus (Waterhouse 1998). In the present study it was reared from Country Bean, Tomato and Mung Bean.

Conclusion: The results indicate the importance of different species of leafminers and their plant hosts especially vegetables in development of strategies for farmer education in the integrated pest management (IPM) programs.

\section{References}

Ahmed, M. (2005). Tea Pest. Evergreen Printing and Packaging, Dhaka, $14 \mathrm{pp}$

Akter, M.S., M.Z.H. Prodhan, M.A. Maleque, M.M. Uddin \& K.H. Kabir (2001). Host plants, Damage severity and seasonal abundance of the leafminer, Liriomyza sp. (Diptera: Agromyzidae). Bangladesh Journal of Zoology 29(2): 193-198.

Alam, M.Z. (1965). Modern Insectidices and Their Uses (An Insect Control Guide). Agriculture Information Service, Department of Agriculture, Dacca, 209pp. 
Alam, M.Z., A. Ahmed, S. Alam \& M.A. Islam (1964). A Review of Research Division of Entomology (1946-1964). Agriculture Information Service, Dacca, 272pp.

Andersen, A., E. Nordhus, V.T. Thang, T.T.T. An, H.Q. Hung \& T. Hofsvang (2002). Polyphagous Liriomyza species (Diptera: Agromyzidae) in vegetables in Vietnam. Tropical Agriculture (Trinidad) 79: 241-246.

Benavent-Corai, J., M. Martinez \& R.J. Peydró (2005). Catalogue of the host-plants of the world Agromyzidae (Diptera). Bollettino di Zoologia Agraria e di Bachicoltura Serie II 37: 1-97.

Bhuiya, B.A., S. Amin \& S. Mazumdar (2011). First report of vegetable leaf miner Liriomyza sativae Blanchard (Diptera: Agromyzidae) through DNA barcoding from Bangladesh. Journal of Taxonomy and Biodiversity Research 5: 17-19.

Bhuiya, B.A., S. Mazumdar, M.K. Pasha, W. Islam, M.I. Miah \& M.S. Hossain (2010). A preliminary report on the agromyzid leaf miner pest attack on some agricultural crops and weeds in Bangladesh. Journal of Taxonomy and Biodiversity Research 4: 47-50.

Biswas, G.C. (2001). Screening of some Soya Bean entries for resistance to stem flies Ophiomyia phaseoli Tryon and Melanagromyza sozae Zehtner and their incidence. Journal of Asiatic Society of Bangladesh, Science 27(1): 101-105.

Braun, M.R., M. Almeida-Neto, R.D. Loyola, A.P. Prado \& T.M. Lewinsohn (2008). New host-plant records for neotropical agromyzids (Diptera: Agromyzidae) from Asteraceae flower heads. Neotropical Entomololgy 37(1): 97-99.

Chen, X., F. Lang, Z. Xu, J. He \& Y. Ma (2003). The occurrence of leafminers and their parasitoids on vegetables and weeds in Hangzhou area, Southeast China. BioControl 48(5): 515-527; http:// www.dx.doi.org/10.1023/A:1025726813462

Chow, A. \& K.M. Heinz (2004). Biological control of leafminers on ornamental crops, pp. 221-238. In: Heinz, K.M., R.G. van Driesche \& M.P. Parrella (eds.). Biocontrol in Protected Culture. Ball Publishing Batavia, Illinois.

Civelek, H.S., Z. Yoldas \& M.R. Ulusoy (2004). Seasonal population trends of Liriomyza huidobrensis (Blanchard, 1926) (Diptera: Agromyzidae) on cucumber (Cucumis sativus L.) in Western Turkey. Journal of Pest Science 77(2): 85-89; http://www.dx.doi. org/10.1007/s10340-003-0032-3

Deeming, J.C. (1992). Liriomyza sativae Blanchard (Diptera: Agromyzidae) established in the Old World. Tropical Pest Management 38(2): 218-219.; http://www.dx.doi. org/10.1080/09670879209371689

Deeming, J.C. \& D.J. Mann (1999). Distributional notes on two economically important Agromyzidae (Dipt.) in West Africa. Entomologist's Monthly Magazine 135: 205-206.

Delfino, M.D. \& D.E. Hardy (1967). A Catalog of the Diptera of the Oriental Region. The University Press of Hawaii, Honolulu, HI.

Dempewolf, M. (2004). Arthropods of Economic Importance Agromyzidae of the World (CD-ROM). ETI. University of Amsterdam, Amsterdam.

Hwang, C.Y. \& H.C. Moon (1995). Effect of temperatures on the development and fecundity of Liriomyza chinensis (Diptera: Agromyzidae). Korean Journal of Applied Entomology 34(1): 65-69.

Kang, L. (1996). Ecology and Sustainable Control of Serpentine Leafminers. Science Press, Beijing, 215pp.

Martinez, M. (1982). Contribution a l'etude des Agromyzidae de France (Dipt.) (2e note). Liriomyza nietzkei Spencer et Liriomyza chinensis (Kato), deux especes d'importance economique presentes en France. Bulletin de la Société entomologique de France 87: 302308.

Martinez, M. \& D. Bordat (1996). Note sur la presence de Liriomyza sativae Blanchard au Soudan et au Cameroun (Diptera: Agromyzidae). Bulletin de la Societe Entomologique de France 101(1): 71-73.

Mia, M.D. (1998). Current status of insect research of pulse crops and future research needs, pp. 87-93. In: Proceedings of The Workshop on Disease Resistance Breeding in Pulses. Thana cereal technology transfer and identification project, Dhaka.
Prodhan, M.Z.H., M.A. Maleque, K.H. Kabir, M.A. Zahid \& M.A. Hossain (2000). Effect of sowing date and variety on the incidence of stemfly (Ophiomyia phaseoli Tryon) in Blackgram. Bangladesh Journal of Entomology 10 (1\&2): 79-86.

Rahman, M.M. (1991). Control measures of important insect pests of major pulses, pp. 139-141. In: Advances in Pulses Research in Bangladesh. Proceedings of the Second National Workshop on Pulses, 6-8 June, 1989, BARI, Joydebpur, Bangladesh.

Rahman, M., M.A. Mannan \& S. Jahan (1983). Insect problems on soybean in Bangladesh. $8^{\text {th }}$ Bangladesh Science Conference, BAAS, Dhaka (Bangladesh).

Rauf, A., B.M. Shepard \& M.W. Johnson (2000). Leafminers in vegetables, ornamental plants and weeds in Indonesia: surveys of host crops, species composition and parasitoids. International Journal of Pest Management 46: 257-266; http://www.dx.doi. org/10.1080/09670870050206028

Sasakawa, M. (1961). A study of the Japanese Agromyzidae (Diptera): Part 2. Pacific Insects 3(2-3): 307-472.

Sasakawa, M. (1963a). A revision of Polinesian Agromyzidae (Diptera). Pacific insects 5(3): 489-506.

Sasakawa, M. (1963b). Papuan Agromyzidae (Diptera). Pacific Insects 5(4): 797-835.

Sasakawa, M. (1997). Lauxaniidae and Agromyzidae (Diptera) of the Ryukyus. ESAKIA 37: 141-148.

Scheffer, S.J. \& M.L. Lewis (2005). Mitochondrial phylogeography of the vegetable pest Liriomyza sativae (Diptera: Agromyzidae): divergent clades and invasive populations. Annals of the Entomological Society of America 98(2): 181-186; http://dx.doi. org/10.1603/0013-8746(2005)098[0181:MPOVPL]2.0.CO;2

Scheffer, S.J., M.L. Lewis \& R.C. Joshi (2006). DNA barcoding applied to invasive leafminers (Diptera: Agromyzidae) in the Philippines. Annals of the Entomological Society of America 99(2): 204-210; http://dx.doi.org/10.1603/0013-8746(2006)099[0204:DBATIL]2.0. $\mathrm{CO} ; 2$

Scheffer, S.J., I.S. Winkler \& B.M. Wiegmann (2007). Phylogenetic relationships within the leaf-mining flies (Diptera: Agromyzidae) inferred from sequence data from multiple genes. Molecular Phylogenetics and Evolution 42(3): 756-775; http://www.dx.doi. org/10.1016/j.ympev.2006.12.018

Sehgal, V.K., M.A. Khan, M. Jyoti, A.K. Sen \& C.K. Mandal (1980). Survey and taxonomic studies on the Agromyzid flies (Diptera) of North India, with specialreference to their host-plant relationships. Final report of ICAR Adhoc Research Scheme (1977-1980), G.B. Pant Univ. of Agric. and Tech., Pantnagar (Nainital) U.P., India, 167pp.

Shahreki, Z., E. Rakhshani \& M. Sasakawa (2012). A Contribution to the agromyzid leaf miners (Diptera: Agromyzidae) of Iran. Biologica nyssana 3(1): 31-36.

Shanower, T.G., S.S. Lal \& V.R. Bhagwat (1998). Biology and management of Melanagromyza obtusa (Malloch) (Diptera: Agromyzidae). Crop Protection 17(3): 249-263; http://www.dx.doi. org/10.1016/S0261-2194(97)00117-8

Shanower, T.G., J. Romeis \& E.M. Minja (1999). Insect pests of pigeonpea and their management. Annual Review of Entomology 44: 77-96; http://www.dx.doi.org/10.1146/annurev.ento.44.1.77

Shiao, S.F. (2004). Morphological diagnosis of six Liriomyza species (Diptera: Agromyzidae) of quarantine importance in Taiwan. Applied Entomology and Zoology 39(1): 27-39; http://dx.doi. org/10.1303/aez.2004.27

Shiao, S.F. \& W.F. Wu (1999). Supplements to the Species of Agromyzinae (Diptera: Agromyzidae) from Taiwan, with notes on three new records. Chinese Journal of Entomology 19: 343-364.

Shiao, S.F., F.J. Lin \& W.F. Wu (1991). Redescription of Four Liriomyza Species (Diptera: Agromyzidae) from Taiwan. Chinese Journal of Entomology 11(1): 65-74

Spencer, K.A. (1965). A classification of the status of Liriomyza trifolii (Burgess) and some related species (Diptera: Agromyzidae). Proceedings of the Entomological Society of Washington 67: 32-40. Spencer, K.A. (1973). Agromyzidae (Diptera) of economic importance. Dr. W. Junk, The Hague, Serie Entomologica, 418pp. 
Spencer, K.A., (1990). Host Specialization of the World Agromyzidae (Diptera). Kluver Academi Publishers, Nedherland, 444pp.

Spencer, K.A. (1999). Family Agromyzidae (Australasian/Oceanian Diptera Catalog); http://hbs.bishopmuseum.org/aocat/ agromyzidae.html

Spencer, K.A. \& G.C. Steyskal (1986). Manual of the Agromyzidae (Diptera) of the United States. U.S. Department of Agriculture, Agriculture Handbook. n. 638. Washington, USA.

Thapa, R.B. (2011). Description of new species of leaf miners (Diptera Agromyzidae) associated with leguminous host described from northern India. Nepalese Journal of Biosciences 1: 66-82; http:// dx.doi.org/10.3126/njbs.v1i0.7474

Walczak, F. \& K. Roik (2010). Short-Term Forecasting and Monitoring of Leaf Miners (Agromyzidae) and Leaf Beetles (Oulema spp.) on Winter Wheat. Journal of Plant Protection Research 50(4): 496-500; http://dx.doi.org/10.2478/v10045-010-0082-5

Waterhouse, D.F. (1998). Biological Control of Insect Pests: Southeast Asian Prospects. Australian Centre for International Agricultural Research (ACIAR)Monograph No. 51, 548pp+viii, 1 fig., 16 maps.
Winkler, I., S.J. Scheffer \& C. Mitter (2009). Molecular phylogeny and systematic of leaf-mining flies (Diptera: Agromyzidae): delimitation of Phytomyza Fallen sensu lato and included species groups, with new insights on morphological and host-use evolution. Systematic Entomology 34: 260-292; http://www.dx.doi.org/10.1111/j.13653113.2008.00462.x/

Yadav, A.K. \& S. Yadav (2013). New record of parasitoids of Melanagromyza obtusa on Cajanus cajan and their review. The Eciscan IV: 123-128.

Zhao, Y.X. \& L. Kang (2002). The role of plant odours in the leafminer Liriomyza sativae (Diptera: Agromyzidae) and its parasitoid Diglyphus isaea (Hymenoptera: Eulophidae): Orientation towards the host habitat. European Journal of Entomology 99: 445-450.

Zhu, C.D., J. LaSalle \& D.W. Huang (2002). A Study of Chinese Cirrospilus Westwood (Hymenoptera: Eulophidae). Zoological Studies 41(1): 23-46. 